\title{
KESAN PENGGUNAAN HITUNGAN ASTRONOMI DAN ALATAN MODEN DALAM CERAPAN HILAL DI MALAYSIA: SATU PENELITIAN
}

\section{The Effects of Astronomical Calculation and Modern Tools in the Crescent Visibility in Malaysia: \\ A Case Study}

\author{
Mohammaddin Abdul Niri * \\ Mohd Saiful Anwar Mohd Nawawi * \\ Khadijah Ismail * \\ Raihana Abdul Wahab * \\ Nurul Huda Ahmad Zaki *
}

\begin{abstract}
Science and technology (S\&T) are necessary as a tool to help Islamic jurists understand related issues explicitly. On the crescent visibility issue, the implementation of $S \& T$ through astronomical calculation and instrumentation is still debated, some accept while others reject. Therefore, this paper will examine the effects arising from the implementation of S\&T. The crescent visibility data for 2010 were analysed to examine the effects. The results showed that $S \& T$ can strengthen the method of rukyah (observation), thereby overcoming the indecision and reducing the fallibility from the observation and the witness. The issued juristic result can also be made accurately and proven scientifically. Without $S \& T$, the result might be supported by weak testimonial, even though the witness is qualified.
\end{abstract}

Keyword: Astronomi Islam, Falak, Hilal, Sains dan Teknologi

Calon-calon Ijazah Doktor Falsafah (PhD), Program Astronomi Islam, Akademi Pengajian Islam, Universiti Malaya, Kuala Lumpur, aayatulrahman@gmail.com. 


\section{PENDAHULUAN}

Peranan sains dan teknologi (S\&T) pada masa kini dalam pengembangan ilmu memang tidak dapat dinafikan. Ini kerana satu daripada kaedah penghasilan pengetahuan dalam pengembangan ilmu moden adalah disumbangkan dari kaedah sains itu sendiri. ${ }^{1}$ Oleh itu, hampir seluruh kehidupan manusia moden dilingkungi dengan aplikasi S\&T. Ini berlaku kerana penerapannya dapat menyelesaikan masalah, mengatasi kesulitan dan memberikan kemudahan. Bertitik tolak dari itu, penelitian dilakukan ke atas pendekatan S\&T iaitu bagaimana ia boleh diterapkan sebagai alat bantu dalam bidang hukum Islam. Dalam penulisan ini isu yang dipilih adalah isu penentuan kenampakan anak bulan.

\section{ISU PENENTUAN KENAMPAKAN HILAL DARI PERSPEKTIF HUKUM}

Berpandukan kepada dalil-dalil syarak daripada al-Quran dan hadis Rasulullah SAW, ${ }^{2}$ para ulama sependapat bahawa apabila

1 Wan Mohamed Wan Muda, "Kaedah Sains dan Pelaksanaan Penyelidikan: Suatu Penilaian Bersepadu", dalam Siri wacana Sejarah dan Falsafah Sains, ed. Mohd. Yusof Othman et al. (Kuala Lumpur: Dewan Bahasa dan Pustaka, 1993), 47.

2 Dalil-dalil al-Quran, "Sesiapa diantara kamu yang menyaksikan anak bulan Ramadan (atau mengetahuinya), maka hendaklah ia berpuasa bulan itu." (al-Baqarah (2): 185). "Mereka bertanya kepadamu (wahai Muhammad) mengenai (peredaran anakbulan). Katakan (peredaran) anak-anak bulan itu menandakan urusan waktu-waktu (urusan) manusia, khasnya ibadat haji." (al-Baqarah (2): 189). "Dialah yang menjadikan matahari bersinar-sinar (terang-benderang) dan bulan bercahaya, dan Dialah yang menentukan perjalanan tiap-tiap satu itu (berpindah-randah) pada tempat-tempat peredarannya masingmasing supaya kamu dapat mengetahui bilangan tahun dan kiraan masa”. (Yūnus (10): 5).

Dalil-dalil Hadis, "Berpuasalah kamu apabila melihat hilal dan berbukalah (berhari raya) sekiranya melihat hilal. Sekiranya mendung, maka sempurnakanlah 30 hari Syaaban." (Diriwayatkan oleh al-Bukhārī dan Muslim). "Jangan kamu berpuasa sehingga kamu melihat hilal dan jangan kamu berbuka sehingga kamu melihat hilal. Sekiranya mendung, maka taqdirkanlah ia." (Diriwayatkan oleh al-Bukhārī). 
anak bulan kelihatan pada hari cerapan hilal iaitu pada hari ke29 Hijrah khususnya bagi bulan Ramadan, Syawal dan Zulhijjah, maka keesokannya boleh ditetapkan sebagai satu hari bulan Hijrah. Namun, apabila hilal tidak kelihatan pada hari tersebut, para ulama berbeza pendapat terhadap kaedah yang perlu digunakan untuk menetapkan awal bulan Hijrah iaitu sama ada pada hari esoknya digenapkan kepada 30 hari, dikenali sebagai kaedah istikmal, ataupun ditentukan melalui kiraan astronomi yang terperinci iaitu sebagai kaedah hisab. ${ }^{3}$ Kaedah istikmal adalah satu cara hitungan penggenapan yang cukup ringkas dan mudah telah digunakan di zaman Rasulullah SAW dan para sahabat. Selanjutnya bermula pada zaman Abbasiyah, aktiviti penyelidikan terhadap kaedah hisab secara meluas apabila ilmu astronomi mula dibangunkan dan dimajukan. ${ }^{4}$

Perselisihan ini berpunca daripada perbezaan tafsiran terhadap nas yang berkaitan dengan penetapan kenampakan hilal iaitu pada lafaz hadis (فاقدروا له). Jumhur ulama iaitu Imam Abu Hanifah (150H/767M), Imam Malik (179H/795M), Imam Shafii (204H/820M), jumhur salaf dan khalaf memberi makna lafaz tersebut sebagai "sempurnakanlah atau lengkapkanlah kepada 30 hari" semata-mata dan bukannya membawa makna taqdirkan kepada hisab kedudukan bulan. ${ }^{5}$

Manakala, menurut Mutarrif bin 'Abd Allah al-Mālikī (220H/835M), Ibn Qutaybah (276H/885M), Abū al-'Abbās bin Surayj al-Shāfi'ī (306H/919M), dan ulama-ulama yang lain, lafaz tersebut bermakna takdirkanlah mengikut hisab (iaitu kiraan) terhadap kedudukan bulan. ${ }^{6}$ Bagi Imam al-Nawawī $(676 \mathrm{H} / 1278 \mathrm{M})$, pendapat yang mentafsir lafaz tersebut kepada hisab adalah tertolak kerana ia adalah perkara yang menyusahkan umat, ia hanya diketahui oleh seorang dua sahaja di negara-negara yang besar serta adanya hadis sahih Nabi SAW yang menyebut, ${ }^{7}$

3 Abū Zakariyyā Muhyi al-Dīn al-Nawawī, al-Majmū' Sharh alMuhadhdhab li al-Shīrāzī (Jeddah: Maktabah al-Irshād, 1980), $6: 276$.

4 Al-Nawawī, al-Majmū 'Sharh al-Muhadhdhab li al-Shīrāzì.

5 Al-Nawawī, al-Majmū ' Sharh al-Muhadhdhab li al-Shīrāzì.

6 Al-Nawawī, al-Majmū' Sharh al-Muhadhdhab li al-Shīrāzì.

7 Al-Nawawī, al-Majmū 'Sharh al-Muhadhdhab li al-Shīrāzī. 
"Sesungguhnya kami adalah umat yang ummi tidak menulis dan tidak mengira". ${ }^{8}$

Aḥmad Shākir $(1377 \mathrm{H} / 1958 \mathrm{M})^{9}$ pula memberi pandangan yang berbeza. Beliau menyatakan semasa zaman pra-Islam dan semasa zaman awal Islam tidak dapat diragui bahawa orang Arab tidak mempunyai pengetahuan saintifik (ma 'rifah 'ilmiyyah jāzimah) tentang astronomi. Mereka merupakan satu komuniti yang buta huruf, maka menulis dan mengira bukanlah menjadi sebahagian budaya lazim mereka. Sesiapa yang mengetahui astronomi pada masa itu hanyalah memahami perkara asas yang diperolehi melalui cerapan, secara tradisi lisan dan laporan. Pengetahuan mereka tentang astronomi tidak berdasarkan pada peraturan matematik dan bukti empirikal. Oleh kerana itu, Nabi Muhammad SAW menetapkan kalendar Islam yang mempunyai keperluan ibadah sesuai dengan ciri-cirinya yang pasti dan boleh dicapai oleh semua orang, iaitu dengan melihat anak bulan menggunakan mata kasar. Ia merupakan piawaian yang terbaik untuk menentukan kitaran waktu. Amalan melihat anak bulan secara tidak langsung membantu mereka mencapai pengetahuan yang boleh dipercayai. ${ }^{10}$

Justeru, apabila masyarakat termasuk pakar dan orang awam sudah mampu mempelajari hisab yang bersifat yakin dan qat $i \bar{\imath}$ dalam penentuan kenampakan anak bulan maka, mereka boleh bergantung kepada kaedah hisab seperti mana mereka bergantung kepada kaedah rukyah. Di samping itu, apabila majoriti sudah boleh mengira maka penyebab hukum ('illah) iaitu buta huruf sudah tidak wujud lagi. Maka adalah menjadi kewajipan untuk mencari kaedah lain yang lebih pasti (al-yaqīn al-thābit). Selanjutnya, ia menjadikan kaedah hisab perlu diterima dalam penentuan awal bulan (ithbāt al-ahilla). Kaedah hisab hanya boleh diketepikan bila kaedah tersebut menjadi sukar untuk ahli masyarakat

\footnotetext{
8 'Abd Allah Muḥammad b. Ismā'il Abū al-Bukhārī, al-Jāmi ‘ alȘaḥ̄h, Kitāb al-Șaum, no. hadith 1913 (al-Qāhirah: al-Maṭba'ah alSalafiyyah, 1403H), 2:32.

9 Ebrahim Moosa, "Shaykh Aḥmad Shākir and the Adoption of a Scientifically-Based Lunar Calendar", Islamic Law and Society 5, no. 1 (1998): 57-89.

10 Ebrahim Moosa, "Shaykh Ahmad Shākir," 77.
} 
mempelajarinya, seperti dalam kawasan luar bandar terpencil dan kampung-kampung yang tidak dapat menerima maklumat dan pengetahuan yang boleh dipercayai daripada orang yang pakar dalam hisab. Justeru, jika hisab perlu diterima kerana hilang sebab hukum ('illah), maka wajiblah dibangunkan pengiraan yang betul berdasarkan pusingan lengkap fasa-fasa bulan. ${ }^{11}$

Mengikut pandangan Yūsuf al-Qaraḍāwī ${ }^{12}$ kaedah istikmal yang dinyatakan oleh nas hadis bukanlah tujuan utama yang ditekankan. Kaedah tersebut ditunjukkan Nabi Muhammad SAW kerana ia adalah cara yang mudah difahami oleh masyarakat awam ketika itu dan agar tidak menyusahkan mereka. Sebaliknya dalam keadaan masyarakat semasa ini yang sudah celik huruf dan angka, cara yang lebih baik untuk mencapai tujuan iaitu menentukan permulaan bulan Hijrah adalah dengan menggunakan hisab iaitu kiraan astronomi. Penerimaan hisab dalam kes anak bulan perlu dilihat dari sudut keutamaan (qiyās awlawi) dimana kaedah hisab bersifat pasti (qat tîl) sedangkan kaedah rukyah bersifat sangkaan $($ zanni $) \cdot{ }^{13}$

Allah berkehendak kepada hamba-Nya dengan sesuatu yang mampu dilaksanakan dan bukannya sesuatu yang susah. Pada zaman Rasulullah SAW, kebanyakan masyarakat adalah buta huruf, jika hisab digunakan sudah tentu akan menyulitkan mereka. Kerana itu, hadis menunjukkan metod yang rendah dan lebih mudah iaitu dengan rukyah dan istikmal. Walau bagaimanapun, kaedah ini masih mempunyai kemungkinan berlakunya keraguan. Terdapat cara yang lebih baik, mustahil berlakunya kesilapan dan pembohongan serta lebih meyakinkan bagi mencapai tujuan nas tersebut iaitu untuk menentukan kenampakan anak bulan, cara tersebut adalah dengan menggunakan kaedah hisab. ${ }^{14}$

Antara ulama mutakhir yang menerima kaedah hisab untuk penentuan kenampakan hilal adalah Muhammad Bakhīt al-

11 Ebrahim Moosa, "Shaykh Ahmad Shākir."

12 Yūsuf al-Qaraḍāwī, Kayf Nata 'āmal Ma 'a al-Sunnah al-Nabawiyyah (al-Qāhirah: Dār al-Shuruq, 2005), 165-173.

13 Al-Qaraḍ̄āī, Kayf Nata 'āmal Ma'a al-Sunnah, 165.

14 Al-Qaraḍ̄̄̄ī, Kayf Nata 'āmal Ma 'a al-Sunnah, 166. 
Muțī'ì (1354H/1935M), ${ }^{15}$ Ṭanțāwī Jawharī (1358H/1940M), ${ }^{16}$ Aḥmad Shākir (1377H/1958M) ${ }^{17}$ dan Mușțafā Aḥmad al-Zarqā' $(1419 \mathrm{H} / 1999 \mathrm{M}) .{ }^{18}$ Mereka menerima penggunaan kaedah hisab dan berpendapat bahawa kesaksian kenampakan hilal boleh dinafikan sekiranya tidak sepadan dengan hisab. ${ }^{19}$

Berdasarkan pandangan para sarjana hukum di atas, beberapa kesimpulan dapat dikenal pasti iaitu:

1. Rukyah adalah kaedah penentuan yang paling asas.

2. Hisab iaitu kiraan astronomi adalah alat bantu kepada kaedah rukyah.

3. Istikmal ialah menggenapkan bulan Hijrah menjadi 30 hari apabila anak bulan tidak kelihatan pada hari ke-29 sama ada secara rukyah ataupun tidak menepati syarat kenampakan yang telah ditetapkan secara hisab.

\section{SAINS DAN TEKNOLOGI SEBAGAI ALAT}

Sains adalah proses ilmiah yang bermula apabila manusia mengamati sesuatu yang berlaku kemudian mencetuskan interaksi manusia melalui kegiatan berfikirnya terhadap alam semesta serta merangkumi kaedah, sikap, aktiviti dan natijah yang terhasil daripada aktiviti ilmu tersebut. Ia berupa suatu pengetahuan yang

15 Muhammad Bakhīit al-Muțīīi, Kitāb Irshād Ahl al-Millah ilā Ithbāt al-Ahillah (al-Qāhirah: Mațba'ah Kurdistan al-'Ilmiyyah, 1911).

16 Țanțāwī Jawharī, al-Qur' ān wa al- 'Ulūm al- 'Așriyyah (al-Qāhirah: Mațba'ah Dār Iḥyā’ al-Kutub al-Arabiyyah, 1923), 28-29.

17 Aḥmad Muḥammad Shākir, Awā'il al-Shuhūr al-'Arabiyya: Hal Yajūz Shar'an Ithbātuhā bi al-Hisāb al-Falakī? Bahth Jadīd 'Ilmī Hurr (al-Qāhirah: Dār al-Istiqāmah, 1992), 1-29.

18 Muștafā al-Zarqāa', "Hawl I'timād al-Ḥisāb al-Falakī li Taḥdīd Bidāyah al-Shuhūr al-Qamāriyyā: Hal Yajūz Shar'an aw Lā Yajūz?", Majjallāt Majma' al-Fiqh al-Islāmī (Dawrah al-Thāniyah li Mu'tamar Majma' al-Fiqh Islāmī, 1986), 2:927-936.

19 Al-Qaraḍ̄̄̄ī, Kayf Nata 'āmal ma 'a al-Sunnah, 165-173. 
mentafsir tentang hakikat alam yang terbit daripada kaedahkaedah yang boleh dipercayai. ${ }^{20}$

Menurut Shaharir (2000), sains merupakan analisis fenomena secara sistematik, mantik dan objektif dengan kaedah khusus yang diperantikan untuk menghasilkan penumpukan pengetahuan yang boleh dipercayai pada suatu tempoh masa. Hasil yang diterbitkan kebenarannya masih bersifat relatif, tetap akan dikaji oleh para sarjana dan akan mengalami perubahan lagi. Sesetengah daripada hasil itu menghasilkan teknologi. ${ }^{21}$ Beliau menggariskan pendekatan sains terdiri daripada beberapa kaedah iaitu kaedah

20 Dalam penulisannya Islam dan Sains Moden, S.H Nasr (2008: 22-23) berpendapat bahawa pentafsiran untuk istilah Arab yang sama bagi maksud sains dalam istilah Inggeris adalah tidak memberi makna yang tepat sama sekali, yakni al- 'ilm dengan science. Sains, seperti mana dalam pemikiran dan pentafsiran massa, adalah bernisbah kepada makna sains moden iaitu pengetahuan yang dikembangkan oleh orang-orang seperti Galileo dan Newton bermula di Eropah sejak kurun ke-17 dengan beberapa andaian yang dibuat berdasarkan ciri-ciri kompleks masa, ruang, jirim dan sebagainya. Sains ini menjadikan kekuasaan hakikat fizikal dan ilmu pengetahuan sebagai bebas daripada jenis hakikat dan ilmu pengetahuan lain yang lebih tinggi iaitu ilmu wahyu (al-naql). Jenis sains inilah yang mengancam Islam lantaran epistemologinya yang ternyata berbeza dengan sifat sains tradisi yang membawa kesatuan ilmu. Sains tradisi wujud sebelum kurun ke-17 seperti ketika zaman Yunani, Islam dan Kristian zaman pertengahan. Berbezanya, kesatuan ilmu yang dimaksudkan pada zaman pra-Islam adalah bersifat kabur dan umum, manakala pada era zaman keemasan peradaban Islam pula kesatuan ilmu tersebut berlandas kepada pemartaban wahyu yang kemudiannya dimajukan secara amali. Istilah sains secara tradisi, yang subur pada zaman keemasan Islam silam, inilah merupakan yang paling tepat maknanya untuk diertikan dengan maksud al-'ilm dalam istilah Arab. Keilmuan yang membawa makna kesatuan (tauhid) terhadap Allah SWT dan telah memajukan peradaban Islam. Bammate, N., "The Status of Science and Technique in Islamic Civilization", Philosophy East and West 9, no. 1/2, (1959): 23-25.

21 Shaharir Mohamad Zain, Pengenalan Sejarah dan Falsafah Sains (Universiti Kebangsaan Malaysia: Bangi, 2000), 29-33. 
intuisi dan heuristik, kaedah induksi, kaedah deduksi dan kaedah empirik. ${ }^{22}$

Secara rasional iaitu melalui kaedah induksi dan deduksi, sains menyusun pengetahuan secara konsisten dan terkumpul. Manakala, secara empirik, sains memisahkan pengetahuan yang dapat dibuktikan dengan fakta yang tidak dapat dibuktikan. Dalam sains, pendekatan ini digabungkan membentuk kaedah ilmiah. ${ }^{23}$ Isu penentuan kenampakan anak bulan dari perspektif ilmu sains dibincangkan di bawah bidang ilmu fizik. Melalui bidang ilmu ini, kiraan dibuat ke atas pergerakan bulan, bumi dan matahari untuk membentuk kriteria. Pelbagai kriteria telah dibangunkan untuk menjelaskan keadaan minimum anak bulan boleh dicerap dan kelihatan secara hakiki. Dari perspektif hukum, ia mesti memenuhi kehendak nas (صوموا لرؤيته). Antara penyelidik yang telah menjalankan kajian moden terhadap kriteria kenampakan

22 Kaedah intuisi adalah kaedah mengikut gerak hati untuk mendapatkan ilmu. Kaedah heuristik ialah kaedah yang menggunakan idea baru untuk menerbitkan subidea yang baru. Kaedah induksi adalah kaedah aruhan iaitu membuat kesimpulan menyeluruh dari maklumat yang terhad. Kaedah deduksi adalah kaedah yang membuat kesimpulan yang terhad berdasarkan maklumat yang banyak. Kaedah empirik adalah kaedah mendapatkan maklumat melalui uji kaji. Shaharir Mohamad Zain, Pengenalan Sejarah dan Falsafah Sains, 36, 43, 51 \& 60. Rujuk juga Asasi Akademi Sains Islam Malaysia, http://www. kesturi.net/archives/category/makalah/page/71, 11 September 2012.

23 Agus Dharma, Peran Sains dan Teknologi dalam Percepatan Pembangunan (Jakarta: Universiti Gunadarma, 2010), 2. 
anak bulan ialah Fotheringham, ${ }^{24}$ Maunder, ${ }^{25}$ Bruin, ${ }^{26} \mathrm{McNally},{ }^{27}$ Ilyas, ${ }^{28}$ Schaefer, ${ }^{29}$ Danjon ${ }^{30}$ dan Odeh. ${ }^{31}$

Sebelum tahun 1970, penentuan awal bulan Ramadan dan Syawal menggunakan kaedah rukyah sahaja. Kemudian, satu deklarasi telah dipersetujui di Istanbul, Turki pada tahun 1978 iaitu anak bulan dikira telah wujud dan boleh kelihatan sekiranya, ketinggian anak bulan setelah matahari terbenam tidak kurang $5^{\circ}$ di atas ufuk dan jarak lengkung bulan dari matahari tidak kurang $8^{\circ}$. Amalan kriteria Istanbul mengalami perubahan untuk pelaksanaan di Malaysia iaitu anak bulan dikira kelihatan apabila, (i) ketinggian anak bulan mestilah tidak kurang $5^{\circ}$ dan jarak lengkung $7.5^{\circ}$ ketika matahari terbenam, atau (ii) umur bulan mestilah tidak kurang 8 jam semasa bulan terbenam. Menurut Ilyas, kriteria ini menggabungkan parameter secara agak sembarangan kerana ia tidak mempertimbangkan nilai penghad kira-kira $6^{\circ}$ untuk altitud bulan dari matahari terbenam. Nilai altitud bulan yang lebih kecil

24 Fotheringham, J.K., "On the Smallest Visible Phase of the Moon," Monthly Notices of the Royal Astronomical Society (1910): 70:527531.

25 Maunder, E. Walter, "On the Smallest Visible Phase of the Moon," The Journal of the British Astronomical Association 21 (1911): 355362.

26 Bruin, F. "The First Visibility of the Lunar Crescent," Vistas in Astronomy 21 (1977): 331-358.

27 McNally, D., "The Length of the Lunar Crescent," Quarterly Journal of the Royal Astronomical Society 24 (1983): 417-429.

28 Ilyas, M., "Lunar Crescent Visibility Criterion and Islamic Calendar", Quarterly Journal of the Royal Astronomical Society 35 (1994): 425461.

29 Schaefer, Bradley E. "An Algorithm for Predicting the Visibility of the Lunar Crescent," Bulletin of the American Astronomical Society 19 (1987): 1042-1043.

30 Fatoohi, Louay J., Stephenson, Francis Richard \& al-Dargazelli, Shetha S. "The Danjon Limit of First Visibility of the Lunar Crescent," The Observatory 118 (1998): 65-72.

31 Odeh, Mohammad Sh., "New Criterion for Lunar Crescent Visibility," Experimental Astronomy 18, (2004): 39-64. 
hanya dapat digunakan untuk pemisahan azimut $(D A Z)$ yang lebih besar. $^{32}$

Pada tahun 1992, penyelarasan kaedah penetapan awal bulan Hijrah khususnya bagi bulan Ramadan, Syawal dan Zulhijjah dilaksanakan dalam kalangan negara anggota MABIMS iaitu Brunei Darussalam, Indonesia, Malaysia dan Singapura. Kriteria yang telah dipersetujui dinamakan sebagai kriteria Imkanur Rukyah iaitu anak bulan dianggap boleh kelihatan apabila, (i) ketika matahari terbenam ketinggian bulan tidak kurang dari $2^{\circ}$ dan jarak lengkung bulan-matahari tidak kurang dari $3^{\circ}$, atau (ii) umur bulan tidak kurang daripada 8 jam ketika bulan terbenam. Mulai tahun 1995, pemakaian kriteria ini telah diperluaskan bagi menentukan kesemua bulan Hijrah dalam kalendar hijrah. ${ }^{33}$

Amalan mencerap hilal di Malaysia pada peringkat awal dilakukan oleh golongan cerdik pandai agama seperti alim ulama, para kadi dan mufti kerana mereka mempunyai pengetahuan yang meluas tentang ilmu falak dan hukum-hukum syarak yang berkaitan. Aktiviti rukyah telah pun dijalankan secara rasmi sejak tahun 1934 oleh Syed Alwi bin Tahir al-Haddad dari menara masjid Sultan Abu Bakar, Johor Bahru. ${ }^{34}$ Mencerap anak bulan secara tradisional dilakukan dengan mata kasar sahaja dan peralatan tradisional yang digunakan ialah tingkap cerapan atau dikenali sebagai gawang anak bulan. ${ }^{35}$ Peralatan ini merupakan alat bantuan cerapan yang ada pada masa itu. Ia mempunyai dua komponen iaitu yang pertama: bingkai, dan kedua: tongkat. Bingkai adalah untuk menentukan lokasi anak bulan. Ia dibuat anjal (boleh dinaikkan dan diturunkan sesuai dengan ketinggian dan lamanya hilal di atas

32 Mohammad Ilyas, Sistem Kalendar Islam Dari Perspektif Astronomi (Kuala Lumpur: Dewan Bahasa dan Pustaka, 1999), 90-91,97.

33 Unit Falak Bahagian Penyelidikan JAKIM, Kaedah Penentuan Awal Ramadhan, Syawal dan Zulhijjah di Malaysia (Putrajaya: Jabatan Kemajuan Islam Malaysia, 2001), 10.

34 Bahagian Hal Ehwal Islam, Jabatan Perdana Menteri, "Pelaksanaan Rukyah dan Hisab di Malaysia", Koleksi Kertas Kerja Seminar Persatuan Falak Syar'i Malaysia (Kuala Lumpur: Persatuan Falak Syari'i Malaysia, 1993), 175.

35 Bahagian Hal Ehwal Islam, "Pelaksanaan Rukyah dan Hisab di Malaysia”, Koleksi Kertas Kerja Seminar Persatuan Falak Syar'i Malaysia. 
ufuk). Yang kedua adalah tongkat biasanya diperbuat daripada besi dengan bahagian atas dibuat bandul yang dilubangkan cukup untuk sebelah sahaja mata untuk mencerap. Gawang anak bulan ini banyak digunakan di Indonesia sehingga hari ini. Ia juga ada digunakan untuk aktiviti cerapan hilal.

Setelah tu, Jabatan Ukur dan Pemetaan Malaysia (JUPEM) pula terlibat dalam usaha mencerap anak bulan dan alat teodolit telah mula digunakan. Teleskop pula mula digunakan dalam cerapan anak bulan di Malaysia pada tahun 1979. ${ }^{36}$ Pada tahun tersebut, Jawatankuasa Rukyah yang terdiri daripada 7 orang telah dilantik oleh Fakulti Pengajian Islam, Universiti Kebangsaan Malaysia untuk menjalankan kajian yang diketuai oleh Haron Din. Ia bertujuan untuk menyelidiki sebab-sebab anak bulan sukar dilihat sejak tahun 1970-an. Cerapan anak bulan dilakukan di 6 tempat iaitu Teluk Kemang, Negeri Sembilan, Johor Bahru, Johor, Pulau Sayak, Kedah, Pontian, Johor, Kuala Sungai Baru, Perlis dan Tanjung Aru, Sabah. Menurut beliau, hanya teodolit sahaja yang digunakan dalam mencerap anak bulan sebelum kajian mereka dibuat.

Dalam cerapan yang dilakukan sebanyak 16 bulan berturutturut bermula pada tahun 1979 hingga 1980, teleskop Questar Seven diperkenalkan sebagai alat mencerap anak bulan. Berikut adalah keterangan yang beliau perincikan mengenai teleskop yang mereka gunakan:

\begin{abstract}
"Alat ini berjejari tujuh (7) inci. Penggunaanya adalah khusus untuk meneropong bulan, bintang dan objek-objek bersinar yang lain di angkasaraya. Alat ini dapat menghasilkan tiga tahap pembesaran iaitu 6x, 80x dan 180x mengikut kehendak pengguna bersesuaian dengan tempat dan ketika. Ketika memerhati anak bulan, pembesaran yang digunakan ialah 80x. Ini dilakukan kerana bidang pandangnya (scope) lebih sesuai dari 130x. kalau pembesaran $130 x$ digunakan, hanya sebahagian sahaja dari
\end{abstract}

36 Haron Din, "Melihat Anak Bulan Di Malaysia: Masalah dan Kemungkinan" (Kertas Kerja Seminar dibentangkan di Universiti Kebangsaan Malaysia, 22-24 Januari 1982). 
bulan akan terlihat, disebabkan oleh pembesaran yang terlalu besar. Apabila bulan sabit dua haribulan telah kelihatan, digunakan juga pembesaran 130x, bagi mempastikanya".

Pada masa kini, aktiviti mencerap anak bulan di setiap negeri di bawah Jabatan Mufti Negeri telah menggunakan teleskop dan dibantu oleh teodolit di bawah kendalian JUPEM. Setiap Jabatan Mufti mempunyai sekurang-kurangnya sebuah teleskop yang digunakan untuk mencerap anak bulan.

Perkembangan peralatan astronomi di Malaysia khususnya dalam cerapan anak bulan mengalami perubahan yang sesuai dengan perkembangan peralatan astronomi di dunia. Pada masa kini, khususnya di Teluk Kemang, cerapan anak bulan dibuat dengan bantuan alatan astronomi seperti teleskop utama, teleskop sekunder, kamera DSLR (Digital Single Lens Reflex), hygrometer, perisian astronomi, dan alat pengukur cahaya (digital light meter). Selanjutnya, penggunaan S\&T iaitu dari aspek hisab dan pemakaian alatan astronomi akan dikaji kesannya terhadap penentuan kenampakan anak bulan.

\section{KESAN APLIKASI S\&T TERHADAP PENENTUAN KENAMPAKAN HILAL}

Menurut Yūsuf al-Qaraḍāwī, tujuan utama yang ditekankan dalam nas hadis adalah penentuan kenampakan anak bulan dan bukannya kaedah yang digunakan. ${ }^{37}$ Kerana itu, hukum yang perlu ditentukan adalah adakah hilal itu kelihatan atau tidak bukannya kaedah apa yang perlu digunakan. Jika kelihatan, maka keesokannya adalah 1 hari bulan Hijrah. Sebaliknya, jika tidak kelihatan, bulan tersebut digenapkan menjadi 30 hari.

Penentuan kenampakan anak bulan boleh dilaksanakan dengan 3 kaedah seperti mana yang telah dijelaskan sebelum ini, iaitu kaedah instrumentasi (iaitu rukyah dengan bantuan alatan astronomi), kaedah hisab dan kaedah istikmal. Selanjutnya, datadata cerapan anak bulan sepanjang tahun 1431H (2010M) (rujuk

37 Al-Qaraḍāwī, Kayf Nata 'āmal ma 'a al-Sunnah, 165-173. 
Lampiran A) digunakan untuk mengenal pasti kesan penggunaan S\&T. Kemudian, data-data tersebut disaring dan hanya data yang dapat ditentukan dengan menggunakan ketiga-tiga kaedah tersebut yang dipilih, dan hasilnya 5 data yang diperolehi.

Jadual 1: Data kenampakan anak bulan bagi tahun 1431H/2010M ${ }^{38}$

\begin{tabular}{|c|c|c|c|c|c|c|c|}
\hline$\dot{z}$ & 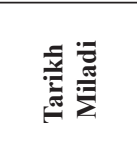 & 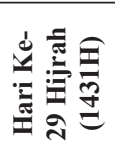 & 总焉 & 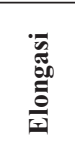 & 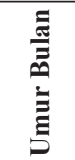 & $\stackrel{\mathscr{E}}{E}$ & 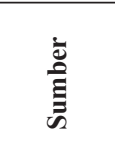 \\
\hline 1 & 14.02 .2010 & Safar & 1.325 & 4.64 & 8.61 & Negatif & $\begin{array}{c}\text { JAKIM/ } \\
\text { UM/ } \\
\text { JUPEM/ } \\
\text { MAINS }\end{array}$ \\
\hline 2 & 14.05 .2010 & $\begin{array}{c}\text { Jamadil } \\
\text { awwal }\end{array}$ & 2.837 & 5.748 & 10.2 & Negatif & $\begin{array}{c}\text { JAKIM/ } \\
\text { UM/ } \\
\text { JUPEM/ } \\
\text { MAINS }\end{array}$ \\
\hline 3 & 12.07 .2010 & Rejab & 6.801 & 8.271 & 15.76 & Positif & $\begin{array}{c}\text { JAKIM/ } \\
\text { UM/ } \\
\text { JUPEM/ } \\
\text { MAINS }\end{array}$ \\
\hline 4 & 10.08 .2010 & Syaaban & 1.855 & 5.446 & 8.27 & Negatif & PPMRR \\
\hline 5 & 08.09 .2010 & Ramadan & -3.211 & 5.086 & 0.76 & Negatif & PPMRR \\
\hline
\end{tabular}

Jadual 2: Jumlah bilangan hari mengikut bulan Hijrah bagi tahun

$1431 H / 2010 M$

\begin{tabular}{|c|l|c|c|c|}
\hline No. & $\begin{array}{c}\text { Hari Ke-29 Hijrah } \\
(\mathbf{1 4 3 1 H )}\end{array}$ & $\begin{array}{c}\text { Instrumentasi } \\
\text { (Rukyah dengan alatan) }\end{array}$ & Hisab & Istikmal \\
\hline 1 & Safar & 30 & 29 & 30 \\
\hline 2 & Jamadilawwal & 30 & 29 & 30 \\
\hline 3 & Rejab & 29 & 29 & 30 \\
\hline 4 & Syaaban & 30 & 29 & 30 \\
\hline 5 & Ramadan & 30 & 30 & 30 \\
\hline
\end{tabular}

38 Kumpulan Fizik Angkasa, Laporan Kajian Kenampakan Hilal. Makmal Fizik Angkasa, Jabatan Fizik, Fakulti Sains, Universiti Malaya; PPMRR merujuk kepada Pejabat Penyimpan Mohor RajaRaja, (2010). 
Graf 1: Jumlah bilangan hari mengikut bulan Hijrah bagi tahun 1431H/2010M

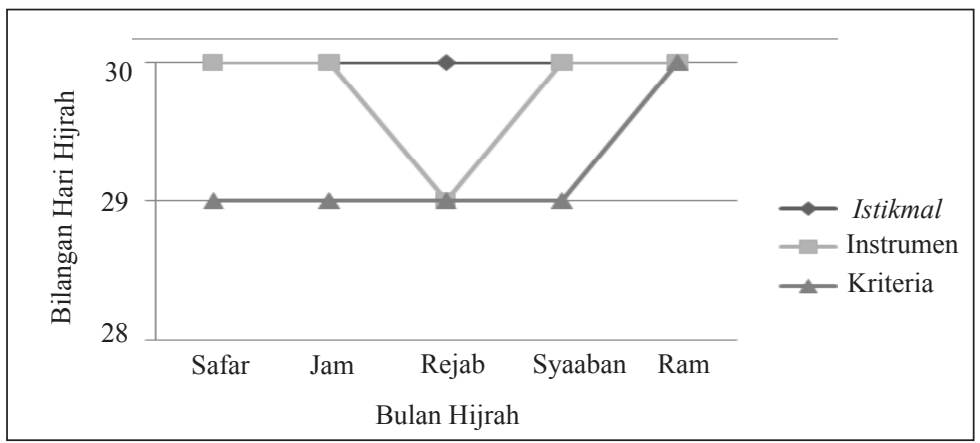

Berdasarkan graf 1 di atas, keputusan daripada kaedah istikmal dan kaedah instrumentasi didapati tidak banyak berbeza dan keduadua kaedah lebih konsisten di antara satu sama lain. Kecuali pada bulan Rejab, cerapan hilal yang dibantu dengan alatan astronomi adalah positif berbanding jika dilakukan dengan mata kasar sahaja. Ini berlaku kerana faktor keamatan cahaya bulan yang rendah menyukarkan cerapan secara mata kasar dilakukan sebaliknya jika dibantu dengan bantuan instrumentasi faktor tersebut dapat diatasi.

Graf 1 juga menunjukkan pendekatan S\&T, iaitu kaedah instrumentasi dan kaedah hisab, dapat berperanan sebagai alat pengesah kesaksian. Contohnya, jika ada sesiapa yang mengakui ada ternampak anak bulan pada hari ke-29 Ramadan $1431 \mathrm{H}$, kesaksian tersebut adalah tertolak dan tidak sah kerana ia tidak memenuhi kriteria. Ini kerana bagaimana anak bulan boleh kelihatan sedangkan bulan ketika itu telah terbenam $\left(-3.211^{\circ}\right)$ terlebih dahulu di bawah ufuk sebelum matahari terbenam. Ini secara tidak langsung menunjukkan kaedah rukyah (tanpa bantuan alatan dan hisab) mempunyai sifat ẓannī dan adanya kemungkinan ralat yang lebih besar berbanding kaedah kriteria yang lebih menonjol dengan sifat qați 


\section{KESIMPULAN}

Perlu difahamai dalam isu kenampakan anak bulan, subjek kajian adalah alam tabii, maka pendekatan S\&T yang digunakan adalah mengikut ilmu sains fizik. Berdasarkan analisis yang telah dibuat terhadap data cerapan, penyelidik mendapati dua peranan yang boleh dimainkan pendekatan S\&T dalam kes ini, pertama, memperbaiki dan mengukuhkan kaedah tradisi menentukan kenampakan hilal yang berasaskan rukyah, dan kedua, menangani keraguan dan kemungkinan berlaku kesilapan pada kaedah rukyah dan pencerap yang menjadi saksi rukyah. Dari segi kesan terhadap hukum, keputusan untuk menetapkan awal bulan Hijrah dapat dibuat dengan lebih saintifik dan tidak sembarangan. Tanpa pendekatan S\&T, keputusan hukum berkemungkinan terhasil daripada kesaksian yang lemah walaupun saksi rukyah adalah seorang yang adil. 
Jurnal Fiqh, No. 9 (2012) 45-64

\section{LAMPIRAN A}

\begin{tabular}{|c|c|c|c|c|c|c|c|}
\hline$\dot{\mathbf{z}}$ & 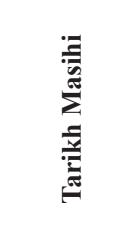 & 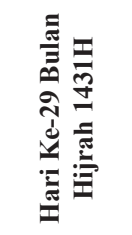 & 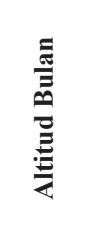 & 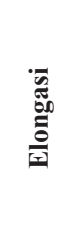 & 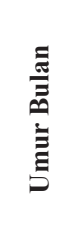 & 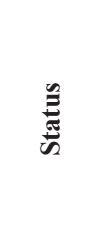 & 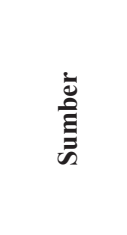 \\
\hline 1 & 15.01 .2010 & Muharram & 0.46 & 1.196 & 4.18 & Kiraan & $\begin{array}{c}\text { Moon } \\
\text { Calculator } \\
6.0\end{array}$ \\
\hline 2 & 14.02 .2010 & Safar & 1.325 & 4.64 & 8.61 & Negatif & $\begin{array}{c}\text { JAKIM/ } \\
\text { UM/ } \\
\text { JUPEM/ } \\
\text { MAINS } \\
\end{array}$ \\
\hline 3 & 15.03 .2010 & $\begin{array}{l}\text { Rabiul } \\
\text { awwal }\end{array}$ & -7.589 & 7.114 & -9.6 & Kiraan & $\begin{array}{c}\text { Moon } \\
\text { Calculator } \\
6.0\end{array}$ \\
\hline 4 & 14.04 .2010 & $\begin{array}{l}\text { Rabiul } \\
\text { akhir }\end{array}$ & -3.745 & 5.45 & -1.18 & Kiraan & $\begin{array}{c}\text { Moon } \\
\text { Calculator } \\
6.0\end{array}$ \\
\hline 5 & 14.05 .2010 & $\begin{array}{c}\text { Jamadil } \\
\text { awwal }\end{array}$ & 2.837 & 5.748 & 10.2 & Negatif & $\begin{array}{c}\text { JAKIM/ } \\
\text { UM/ } \\
\text { JUPEM/ } \\
\text { MAINS }\end{array}$ \\
\hline 6 & 12.06 .2010 & $\begin{array}{l}\text { Jamadil } \\
\text { akhir }\end{array}$ & -1.044 & 2.087 & 0.09 & Kiraan & $\begin{array}{c}\text { Moon } \\
\text { Calculator } \\
6.0\end{array}$ \\
\hline 7 & 12.07 .2010 & Rejab & 6.801 & 8.271 & 15.76 & Positif & $\begin{array}{c}\text { JAKIM/ } \\
\text { UM/ } \\
\text { JUPEM/ } \\
\text { MAINS }\end{array}$ \\
\hline 8 & 10.08 .2010 & Syaaban & 1.855 & 5.446 & 8.27 & Negatif & PPMRR \\
\hline 9 & 08.09 .2010 & Ramadan & -3.211 & 5.086 & 0.76 & Negatif & PPMRR \\
\hline 10 & 08.10 .2010 & Syawal & 4.515 & 10.03 & 16.33 & Kiraan & $\begin{array}{c}\text { Moon } \\
\text { Calculator } \\
6.0\end{array}$ \\
\hline 11 & 06.11 .2010 & Zulqaedah & 0.533 & 4.73 & 6.09 & Kiraan & $\begin{array}{c}\text { Moon } \\
\text { Calculator } \\
6.0\end{array}$ \\
\hline 12 & 05.12 .2010 & Zulhijjah & -5.579 & 4.912 & -6.54 & Kiraan & $\begin{array}{c}\text { Moon } \\
\text { Calculator } \\
6.0\end{array}$ \\
\hline
\end{tabular}




\section{BIBLIOGRAFI}

Agus Dharma. Peran Sains dan Teknologi dalam Percepatan Pembangunan. Jakarta: Universiti Gunadarma, 2010.

Aḥmad Muḥammad Shākir. Awā'il al-Shuhūr al- 'Arabiyya: Hal Yajūz Shar'an Ithbātuhā bi al-Hisāb al-Falakī? Bahth Jad̄̄d 'Ilmī Hur. Al-Qāhirah: Dār al-Istiqāmah, 1992.

Al-Bukhārī, 'Abd Allah Muḥammad b. Ismā'il. Al-Jāmi'al-Ṣahīh. Jil. 2. Al-Qāhirah: al-Mațba'ah al-Salafiyyah, 1403H.

Al-Muțị'ī, Muḥammad Bakhīt. Kitāb Irshād Ahl al-Millah ilā Ithbāt al-Ahillah. Al-Qāhirah: Mațba'ah Kurdistan al'Ilmiyyah, 1911.

Al-Nawawī, Abū Zakariyyā Muḥy al-Dīn. Al-Majmū’ Sharḥ al-Muhadhdhab li al-Shìrāzì. Jil. 6. Jeddah: Maktabah alIrshad, 1980.

Al-Qaraḍāwī, Yūsuf. Kayf Nata'āmal ma'a al-Sunnah alNabawiyyah. Al-Qāhirah: Dār al-Shuruq, 2005.

Bahagian Hal Ehwal Islam, Jabatan Perdana Menteri. "Pelaksanaan Rukyah dan Hisab di Malaysia." Koleksi Kertas Kerja Seminar Persatuan Falak Syar 'i Malaysia. Kuala Lumpur: Persatuan Falak Syari'i Malaysia, 1993.

Bammate, N. "The Status of Science and Technique in Islamic Civilization." Philosophy East and West 9, no. 1/2 (1959): 23-25.

Bruin, F. "The First Visibility of the Lunar Crescent." Vistas in Astronomy 21, (1977): 331-358.

Ebrahim Moosa. "Shaykh Ahmad Shākir and the Adoption of A Scientifically-Based Lunar Calendar." Islamic Law and Society 5, no. 1 (1998): 57-89.

Fatoohi, Louay J. Stephenson, Francis Richard \& al-Dargazelli, Shetha S. "The Danjon Limit of First Visibility of the Lunar Crescent." The Observatory 118 (1998): 65-72. 
Fotheringham, J.K. "On the Smallest Visible Phase of the Moon." Monthly Notices of the Royal Astronomical Society 70 (1910): 527-531.

Haron Din. "Melihat Anak Bulan Di Malaysia: Masalah dan Kemungkinan." Kertas Kerja Seminar dibentangkan di Universiti Kebangsaan Malaysia, 22-24 Januari 1982.

Ilyas, M. "Lunar Crescent Visibility Criterion and Islamic Calendar." Quarterly Journal of the Royal Astronomical Society 35 (1994): 425-461.

Ilyas, M. Sistem Kalendar Islam Dari Perspektif Astronomi. Kuala Lumpur: Dewan Bahasa dan Pustaka, 1999.

Maunder, E. Walter. "On the Smallest Visible Phase of the Moon." The Journal of the British Astronomical Association 21 (1911): 355-362.

McNally, D. "The Length of the Lunar Crescent." Quarterly Journal of the Royal Astronomical Society 24, (1983): 417429.

Odeh, Mohammad Sh. "New Criterion for Lunar Crescent Visibility." Experimental Astronomy 18 (2004): 39-64.

Schaefer, Bradley E. "An Algorithm for Predicting the Visibility of the Lunar Crescent." Bulletin of the American Astronomical Society 19 (1987): 1042-1043.

Shaharir Mohamad Zain. Pengenalan Sejarah dan Falsafah Sains. Universiti Kebangsaan Malaysia: Bangi, 2000.

Ṭanțāwī Jawharī. Al-Qur'ān wa al- 'Ulūm al- 'Așriyyā. Al-Qāhirah: Maṭba'ah Dār Iḥyā' al-Kutub al-Arabiyya, 1923.

Unit Falak Bahagian Penyelidikan JAKIM. Kaedah Penentuan Awal Ramadhan, Syawal dan Zulhijjah di Malaysia. Putrajaya: Jabatan Kemajuan Islam Malaysia, 2001. 
Wan Mohamed Wan Muda. "Kaedah Sains dan Pelaksanaan Penyelidikan: Suatu Penilaian Bersepadu." Dalam Siri wacana Sejarah dan Falsafah Sains. Ed. Mohd. Yusof Othman et al. Kuala Lumpur: Dewan Bahasa dan Pustaka, 1993.

Al-Zarqā', Muștafā. "Ḥawl I'timād al-Ḥisāb al-Falakī li Taḥdīd Bidāyah al-Shuhūr al-Qamariyyā: Hal Yajūz Shar'an aw La Yajūz?", Majjallāt Majma' al-Fiqh al-Islāmī. Dawrah alThāniyah li Mu’tamar Majma' al-Fiqh Islāmī. Jil. 2. 1986. 
Jurnal Fiqh, No. 9 (2012) 45-64 